European journal of American studies

\title{
"You Must Become Dreamy": Complicating Japanese-American Pictorialism and the Early Twentieth-Century Regional West
}

Rachel Sailor

\section{OpenEdition}

\section{Journals}

Electronic version

URL: https://journals.openedition.org/ejas/10405

DOI: $10.4000 /$ ejas. 10405

ISSN: 1991-9336

Publisher

European Association for American Studies

Electronic reference

Rachel Sailor, "'You Must Become Dreamy": Complicating Japanese-American Pictorialism and the Early Twentieth-Century Regional West", European journal of American studies [Online], 9-3 | 2014, document 5, Online since 23 December 2014, connection on 08 July 2021. URL: http:// journals.openedition.org/ejas/10405; DOI: https://doi.org/10.4000/ejas.10405

This text was automatically generated on 8 July 2021 .

Creative Commons License 


\title{
"You Must Become Dreamy": Complicating Japanese-American Pictorialism and the Early Twentieth-Century Regional West
}

\author{
Rachel Sailor
}

\section{Introduction}

1 Kyo Koike (1874-1947) was one of the most active and eager members of the Seattle Camera Club, an association of Seattle-based amateur photographers founded in 1924, in the 1920s and 1930s. His photographs present the Pacific Northwest landscapes around Seattle, with a particular focus on mountain photography, especially Mt. Rainier. Koike's attention to the peaks, alpine meadows, and glaciers in the region fell in line with the interests of a vast army of weekend pictorialists-those who sought picturesque subjects to produce self-consciously artful photographs-from across America. These amateurs embraced the natural areas of their locales to explore the aesthetics and attitudes that defined their approach to photography and their region. Through his tenacious search for subject matter and his pointed interest in the conversations taking place about photography in his city, his nation, and the larger world, Koike left an indelible mark on the pictorialist community and typifies the photographers of the era who conflated the style of pictorialism with regionalist expression.

2 Koike was one of many Japanese-American regionalist photographers in the Pacific Northwest, along with Iwao Matsushida, Frank Asakichi Kunishige, Kusutora Matsuki, Fred Yutaka Ogasawara, and others. Similarly, Hiromu Kira, Kentaro Nakamura, and Shigemi Uyeda were working in Los Angeles in the same period, as did Japanese photographers in other cities along the coast and in Hawaii (Reed 29). These photographers were either first- or, less often, second-generation immigrants from 
Japan-Issei and Nissei, respectively (collectively Nikkei)-who used pictorialist landscape photography to explore picturesque views of their region. Like so many in America during the early twentieth century, they took up photography as a pastime, eager to use the increasing accessibility of the medium to express the sense of place that was at a height of popularity. Koike arrived in Seattle in 1916, quickly found a community of like-minded photographers, and went on to be instrumental in the establishment and operation of the Seattle Camera Club in 1924.

3 The classification of Koike and other members of the Seattle Camera Club as merely "western," or "regional," does not immediately convey the cultural complexity that these photographers and their images of western American places demonstrate. Rather, Koike's pictorialist practice, his Japanese heritage, his adoption of a new locale and the era's attending trends in regionalist thought complicates the typical understanding of what regional cultural production was at that time. In fact, his work demonstrates and exemplifies a nuanced and multifaceted transnational nexus of overlapping cultures, competing aesthetics, and colliding photographic histories that is not only representative of his particular situation, but that also reflects the much larger reality of west coast Japanese immigrant pictorialists and the even larger relationship between immigration and regionalist expression.

4 Ultimately, this essay will be devoted to the story of Koike and his work as a way to demonstrate an expanded notion of regionalism. I believe that pictorialist photographs and their relationship to places are "dense palimpsests of broader forces," as suggested by Douglas Reichert Powell in 2007 about regionalism in general (19). Indeed, broader forces were at work in Koike's photography. As well, I will show that the notion of "region" is not confining or limiting, but a broad and malleable parameter that can help us understand the intricacies and complexity of myriad cultural intersections. First, I will discuss the relationship between photographic pictorialism and pictorial techniques popularized in Japan. By acknowledging the evolution of "Japonisme"in the western world, we can more fully comprehend the inherent aesthetic complexity of Nikkei photography in America. Then I will explore pictorialism as a strong and largely overlooked regional mode of expression-one that found particular favor in the American West. Finally, I will show that the particularly unique photographic heritage of the American West can expand our understanding of the relationship between regional expression and the pictorial aesthetic. Overall, this case study reveals regional pictorialism as a vital force that helped shape the dynamism of early twentieth-century American culture.

\section{Pictorialism and the Japanese Aesthetic}

5 As an aesthetic movement, photographic pictorialism in the American West was coterminous with the rise of regionalism, which reached its height in the late 1920s and 1930s. But, despite the obvious connection at the time, pictorialism is now more commonly understood within the discourse of photographic style development instead of through its relationship to larger cultural trends in America. The photographic style as a product of the regionalist impulse has gone largely unexplored for many reasons. First, pictorialism was an approach to photography that was overthrown (seemingly) by the modernist movement, in America first mounted in art photography by Alfred Stieglitz and his famous image, The Steerage, from 1907 (Peterson 13-17). Second, the 
hegemony of New York and the upper East Coast in the early twentieth-century American art world seemed close to absolute. In the third and fourth decade of the century, despite an interest in western lands by many artists-most notably Georgia o'Keeffe, Edward Weston, Ansel Adams and Group f/64-the West was still considered a cultural backwater, its precise attraction for many modernists (Corn 253). Finally, that pictorialism in the West is not a common scholarly subject has to do with the nature of regionalism-the conceptual home for amateur and hobbyist pictorialists-that was by definition splintered and decentralized.

6 Aesthetically, pictorialism was an approach to photography that emphasized romantic artfulness. Through the use of soft focus lenses, textured paper, and selfconscious compositional techniques borrowed from trends in painting and printmaking, the style was originally an effort to legitimize the mechanical medium of photography. Begun in the late nineteenth century in Europe by Henry Peach Robinson and encouraged through organizations like the Brotherhood of the Linked Ring, pictorialism was for a time associated with the avant-garde of the fine arts. While never really accepted in the nineteenth century as artists equal to painters, pictorialists aggressively co-opted their fine art technique and conceptual approach. For example, the craftsmanship of a pictorialist photograph was a response to the pervasive Arts and Crafts Movement that championed high quality workmanship and an insistence on aesthetic beauty. Moreover, the approach to photography drew heavily on symbolist sentiment in avant-garde art from the turn-of-the-century; imagery in pictorial photography emphasized archetypes and favored universal motifs (Bunnell 5-12).

7 Koike's ca. 1930 photograph, The Serpent, for instance, shows in soft focus the Cascade Range of Washington state with a river winding through the landscape; the terrain is rugged and the atmosphere misty (Fig. 1). The photograph looks like so many others from that time and place, and yet the cultural complexity of its making is striking. Koike's image, for instance, highlights the hazy atmosphere that pictorialists favored, originally meant to align photography with the impasto brushwork of romantic painting generally, and turn-of-the-century symbolist work, specifically. While the Pacific Northwest lent itself to misty landscape representations, the aesthetic effect is deepened by Koike's emphasis on dark shadows across the valley. Ironically, however, like contemporary modernist photographers, Koike intentionally emphasized visual clarity, despite the general cloudiness in the region. In "My Photographic Trip" (1934), Koike wrote that "I like straight photography and most of my enlarged prints are made out from the negative framed on the enlarging easel. I do not believe in printing-in clouds or any other 'faking"' (130). Despite an emphasis on un-manipulated photographs, a tactic not as uncommon as one might think (Cornell 295), a pictorialist approach is also communicated through the title. Koike imagines the winding river as a serpent, anthropomorphizing the elements of this landscape and evoking a mysterious and living sublimity. 
Figure 1

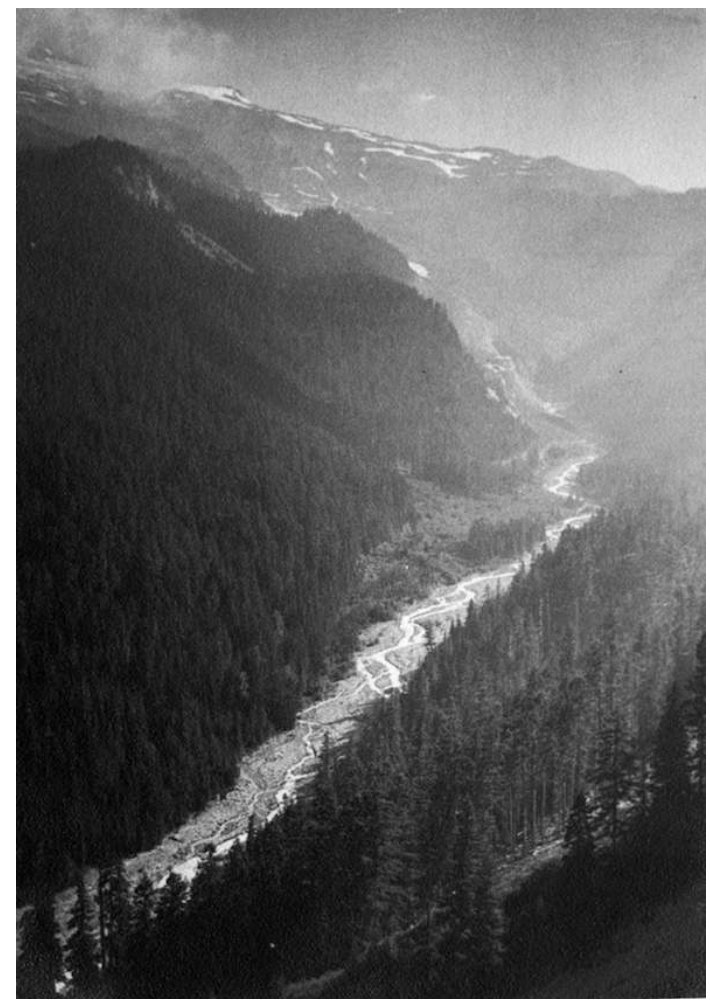

Kyo Koike, The Serpent, ca. 1930 (University of Washington Special Collections, UW 29066z)

8 At the heart of the inspired art movements of the late nineteenth century was an aesthetic borrowing from the Japanese. "Japonisme,"as the craze was dubbed, consumed Europeans and Americans alike. The Japanese aesthetic of ukiyo-e pictures, of asymmetry, flat planes of color or tone that emphasize negative space, aggressive cropping, and general insistence on planes, challenged western artists to reevaluate their own constructs of pictorial space, which had been introduced and codified in the Renaissance. Along with well-known craftsmen such as William Morris and Louis Comfort Tiffany, and avant-garde painters from James Abbott McNeill Whistler in the 1860s to the Belle Epoque's Gustav Klimt, pictorial photographers utilized the new aesthetic to make spare images that foregrounded aesthetic beauty and contrived pictorial space. These images tried to shed the emphasis on absolute clarity and accuracy that had attended photography, as a "mirror with a memory," since its inception (Holmes 739). Despite the deeply interconnected nature of pictorialism and more condoned high art forms, it was vilified as unoriginal from its beginning. In 1898, for instance, Japanese-American art critic Sadakichi Hartmann wrote that

Amateur photography, apparently accessible to every one who can press the button, and reminding one, even with the crudest handling, somewhat of pictorial art, has taken hold of the public taste to such an extent that the Kodak fiend has been made into a typical figure and has had to play his ridiculous part on the stage and in the comical magazines for years. ("A Few Reflections" 41)

"Since amateur photographers are as plentiful as bicyclists," he continued, "the more astonishing it seems to one that those men who really produce something artistic can be counted on the fingers of one hand" (ibid.). Despite its critical rejection, pictorialism flourished precisely because of Eastman Kodak's do-it-yourself technology that allowed 
such broad access to photography. When the first hand-held "Brownie" cameras were sold in 1900 , photography became widely available and was taken up with enthusiasm by the masses.

10 The amateur pictorialists, eager to defend their interests against the rising tide of modernism, returned the disdain that was directed at them. In 1918, for instance, one writer for Photo-Era pondered "to what lengths adherents of straight-photography would go":

If a devotee of straight-photography were out in the woods and found a pleasing bit of landscape, would he hesitate to remove any little objectionable shrub or growth that would mar the harmony of his composition? No, he would not. Would he hesitate to plant a few reeds or twigs if he found that they would add to the beauty of them? Decidedly not. Would he have any conscientious scruples to overexpose or underexpose his plate, for the purpose of obtaining a certain mood or impression? No, of course not, why should he? Then, too, when he develops his negative, would he pause and ponder upon the advisability to overdevelop or underdevelop it to work out his idea? Why no, that is absurd. Would he stop with the straight result of his negative in the case of the society-lady with the crooked mouth? No, he would not; nor would he have any squirms of conscience about strengthening the eyebrows or lashes, or, in fact, changing the entire features so as to make her as beautiful as it is in his power to make her. He would do all these things mentioned, and more, and then calmly sit down and rant against control or interference. You who preach straight-photography should never do any of these things. (Christiansen 190)

11 Despite the tension between artists and photographers and between the two camps of photography in the first decades of the twentieth century, pictorialism was on the upswing.

12 In 1890s America, pictorialism was promoted and demonstrated by Alfred Stieglitz, Edward Steichen, and other members of New York's own Photo-Secession group, so named for their intent to break "away from the narrow rules of custom and tradition" like the Secessionist group in Munich (Stieglitz 534). Stieglitz, especially, worked tirelessly to promote the style in particular and photography as an art form. He opened The Little Galleries of the Photo-Secession out of his home at 291, $5^{\text {th }}$ Ave, New York City, in 1905, produced the Arts and Crafts-inspired periodical Camera Work to showcase the photographs, and gathered around him a group of influential artists and patrons.

${ }_{13}$ Stieglitz was so central to the Photo-Secession group and the art photography movement in America that he remains an iconic figure. The story of his conversion to a straight aesthetic in the early twentieth century, for instance, has become synecdochic for the larger cultural transfer to modernistic photography. Stieglitz's realization while viewing the lower deck on a ship, that he photographed a "spontaneous discovery" has ascended into legend (McCauley 30). Stieglitz did not live or work in a vacuum, however, and others, including art critic Sadakichi Hartmann, had been advocating for this turn in approach and subject matter for years prior. In 1902, the year Stieglitz formed the Photo-Secession, Hartmann bemoaned the trite and formulaic handling of subject matter by the "art photographer," and suggested that photographers expend their efforts on the "ceaseless, ever-shifting stream of humanity in the shopping districts, the Saturday afternoon parade on Broadway after the matinees are over," and "the bustle on the piers at the arrival or departure of an ocean steamer" "Subject and Treatment" 180). Despite this type of early criticism of pictorialism, the narrative of the 
making of The Steerage continues to act as a crucial anecdote around which the history of American photography revolves.

14 Regardless of a broad critical onslaught within the ranks of the fine arts elite, pictorialism continued to thrive well past Stieglitz's conversion to modernism. In fact, in the years following The Steerage, and the almost immediate esteem that "straight" photography received, pictorialism continued to flourish. Through the 1910s, 1920s, and 1930s, interest in pictorialism grew as amateur camera clubs sprouted across America. In the West, as well, pictorialism gained traction, largely because of its strong connection to the rising tide of regionalism between the wars.

15 The evidence for the popularity of photographic pictorialism during this period exists in the records of camera clubs, in the number of journals dedicated to the topic, and in the success of organizing bodies like the Associated Camera Clubs of Americaand Pictorial Photographers of America, organizations that provided unity and solidarity to photographers across the country. Pictorial Photographers of Americawas formed in 1916 by Clarence White with the objective to pick up where the Photo-Secession had left off, producing five lavish Annuals of the Pictorial Photographers of America between 1920 and 1929 (Anderson 206). While those publications certainly demonstrated the popularity of pictorialism, more important were the monthly journals that served photographers. With the rise of Kodak and the weekend hobbyist, photographic journals morphed from catering to the photographic professional of the nineteenth century to addressing the broader concerns of dabblers. Journals such as Photo-Era (1898-1932), American Photography (1907-1953), Abel's Photographic Weekly (1907-1934),and Camera Craft (1900-1942) either made a concerted effort to update their content or were developed afresh.

16 On a more local level, camera clubs proved incredibly important for the success of pictorialism. The clubs organized salons, had public programming, and sometimes even provided darkroom facilities (Peterson 127). Even as early as 1900 the club phenomenon was notable. Hartmann wrote in 1900 that "the New York Camera Club is to-day the leading photographic club of the States, whose influence is most powerful and far felt" ("New York Camera Club" 60). In 1901, however, the California Camera Club was the largest in the world with a membership topping four hundred, despite the New York club's hegemony (“A Mistaken Impression”; Stellmann 171). Ultimately, Hartmann praised the exclusivity of the New York club and all its 340 members. As a way to establish pictorial photography as a legitimate art, the club's strict control over taste and production helped solidify their cause. Things quickly changed, however. By 1905 Hartmann, in a statement that presaged the regionalist movement, wrote that "the mission of photography is, after all, a democratic one" and that "it answers better than other mediums of pictorial expression the special necessities of a leveling age like ours" ("A Plea" 469). In 1912, fifty clubs in the U.S. and Canada were listed. In 1925 the American Annual of Photography listed sixty-seven clubs (Brown 131). In the Seattle Camera Club of that year, Koike reported just over fifty members ("Seattle Camera Club" 186). By 1944 the Encyclopedia of Photography reported that "[d]uring the past several years there has been a marked increase in the number of amateur photographers in the United States" and that "[t]his has been accompanied by a corresponding increase in the number of camera clubs in all sections of the country" (Bent 544). By the early 1940s, camera clubs existed in every city and even in smaller towns across America. The number of clubs listed by organizations and in publications, 
however, did not account for all the clubs in small towns and on university campuses across the West. Indeed, "if agreeable to you," wrote one advocate, "it would probably be possible to organize a camera club in your Y. M. C. A., or your church, your school, social center, or lodge" (Harter 276). Indeed, camera clubs and pictorial photographers were ubiquitous.

17 Kyo Koike was deeply involved with the organizations and publications that promoted pictorialism-in his own region and beyond. As one of the central paradoxes of regionalism and certainly of pictorialist regionalism, Koike, like so many others, regularly participated in national and international salons. Koike submitted photographs to juried exhibitions across the United States from New York, Niagara, and Buffalo to Akron, Memphis, Minneapolis, Houston, Los Angeles, and Portland. Internationally, he exhibited even more widely. He submitted, was accepted, and often won prizes in England, Sweden, Norway, Finland, France, Italy, Yugoslavia, German, Hungary, Greece, Japan, China, India, Australia, and elsewhere (Koike Photograph Collection). He also promoted and judged salons in his own Northwest region and produced an official newsletter of the Seattle Camera Club ("Pictorial Photographic Salons" 36). Notan, the name of the newsletter, was the Japanese word for "darks and lights in harmonic relations," a central concept in the melding of the Japanese aesthetic and black and white photography (Dow 113).

\section{Contested Aesthetics}

Notan functioned as an umbrella concept that could unite all the members of the Seattle Camera Club, Japanese or not, and Koike's use of the term demonstrated his curiosity about the manner in which he would fit into the new social schemes of his adopted home. Koike spent a significant portion of his published material defending and defining the uniquely Japanese qualities that influenced his pictorial work.

19 Despite the Japanese origins of an aesthetic favored by pictorialists, by the $1920 \mathrm{~s}$ many photographers had lost touch with the concept. Koike's desire to defend the Japanese approach was a response to direct criticism from within the ranks of American pictorialism. Ironically, many photographers failed to grasp the centrality that the Japanese had to the style.According to Koike, F.C. Tilney, for instance, wrote that Japanese pictorialists had "a racial bent for decoration" that "leads the Japanese photographers to select arrangements that are not pictorial in our sense of the word, but queer rather" ("Japanese Art in Photography" 113). Koike responded by writing that he was "sorry" that Tilney had "no correct knowledge about Japanese ideas" (qtd. in Reed 57). One participant criticized Seattle's Salon, suggesting that "[i]t is considered in the East that in endeavoring to make the Seattle Salon international in character they will throw out superior American work to make room for inferior foreign work," an accusation that Koike adamantly denied ("Pictorial Photographic Salons" 39; "Influence"). Others, however, recognized the unique Japanese aesthetic as a desirable component of pictorial expression. Sigismund Blumann, editor of Camera Craft, for instance, wrote in 1925 that "it is becoming an accepted belief that this people are not only advancing in abstract pictorialism but are impressing something national, something decidedly characteristic upon our art" and that the Japanese "are actually transforming the stereotyped Salon formula into real novelty" (109). 
20 His writing leaves no doubt that Koike felt different from "the Americans." He referred to his sense of separation from Americans more than once and certainly took pride in his Japanese artistic heritage. He also acknowledged the hybridity in his photographs, saying that "of course my ideas are influenced by foreign conceptions" and that he was "not free from the influence of the Japanese spirit" ("Photographic Trip" 130). However, northwest Washington was his home and the mountains in the region, such as Rainier, Adams, Baker, and St. Helen's, were his preferred subject matter ("Mountain Photography"; "Figures in Mountain Photography"; "Photographing Mountains"). His story demonstrates that being a regionalist, and the strong sense of belonging that was implied, was fluid and complex. Although others contested his aesthetic approach as "foreign," Koike was clear about his position as an immigrant:

Now we are all Japanese living in America. You see it is clear what the members of the Seattle Camera Club should do for the advancement of photographic art. Yes, we must be the best interpreters for both nations, because we are not free of Japanese ideas, and yet at the same time we understand Western ways. We should not make our pictures aimlessly, but must try hard to combine both ideas, in other words stick to our peculiar point of view. ("Seattle Camera Club" 188)

While these exchanges acknowledge Japanese aesthetics in general, they also emphasize the "otherness" that Americans saw in the Japanese-a difference that would be exacerbated by the Second World War.

22 In The Serpent, Koike demonstrated an aesthetic adherence to the earlier romantic traditions by employing "Japonisme" as a compositional technique. The overall tonal quality of the image emphasizes its two-dimensionality-especially when compared to the extreme depth of field sought by Koike's contemporaries in Group f/64. As a result, the river winds across the surface of the photograph, as much as it does through the landscape. As well, its diagonal orientation creates an asymmetry that contrasts with the more canonical photographic approach to a river valley that would juxtapose near and far in a picturesque manner. Overall, Koike's photograph achieves the desired ambiguity so stressed in the Japanese aesthetic. It is neither perfectly rendered as an illusionistically three-dimensional landscape, nor do the scales tip too far into abstraction. It is a balancing act, an aesthetic duality that denies the viewers' ability to see it either way.

23 In another photograph from ca. 1930, Mountains and Tree Branches in the Mist, Koike employed a Japanese technique of juxtaposing the very near and the very far in an attempt to create spatial equilibrium between them (Fig. 2). In this photograph a disembodied branch from a foreground tree interrupts the view across the valley. The foregrounded tree is darker than the distant mountains and displays a delicate intricacy of branches and needles. In the Japanese approach, the branch is not simply something to look past. Rather, it has a visual weight that competes successfully with the distant view to the horizon. The effect is to bring the viewers' attention to the picture plane. We are encouraged by this composition to look near the surface of the photograph, not into and through it in a manner more in line with approaches developed by western culture. The imposing tree, along with the curving line of the middle-ground mountain ridge in the lower right corner emphatically denies an indexical reading of the photograph, and heightens pictorial abstraction. The photograph is thus about the formal qualities of rhythm, balance, texture, and artful composition as much as it is about a specific place and landscape. 
Figure 2

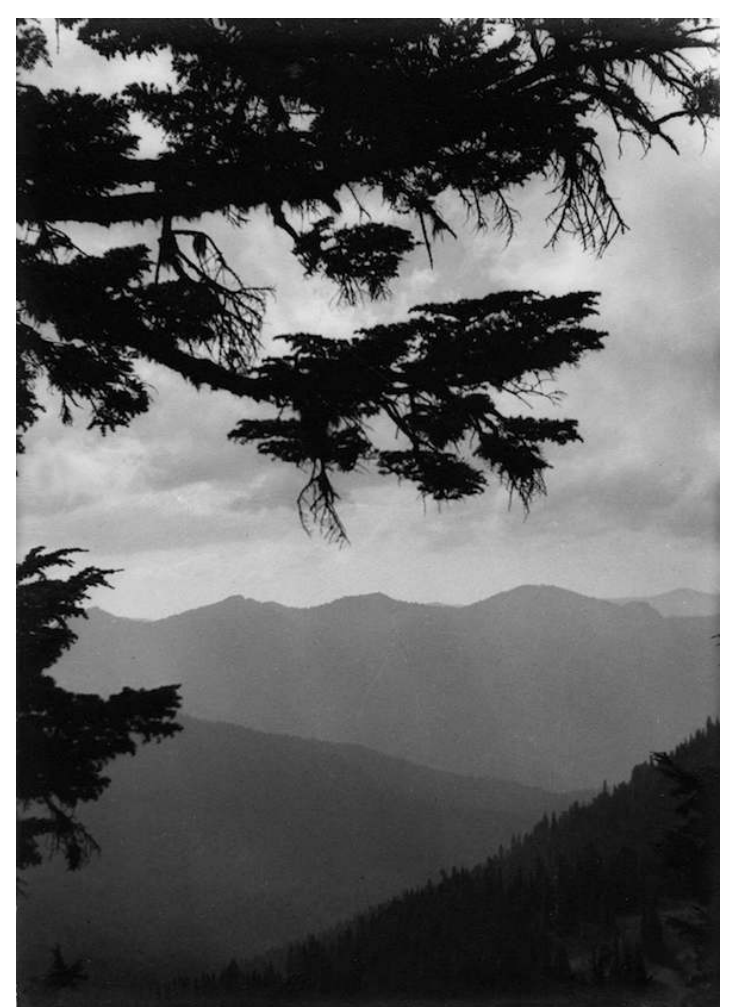

Kyo Koike, Mountains and Tree Branches in the Mist,ca. 1930 (University of Washington Special Collections, UW 29038)

\section{Pictorialism and Region in the American West}

In the American West, especially, pictorial photography at first seems to exemplify the typical understanding of regional production as it related to a national context-that pits the regional margins against the cultural urban centers of the East. In this model, a vast separation exists between regional cultural production that related only to a minority of Americans, and the more expansive work that could speak broadly for all. In another approach, regional cultural production did just the opposite. That is, the work emerging from different regions acted as an exemplar of America-the part was representing the whole. The latter concept was especially related to the American West since the late-nineteenth-century ideas about the American Frontier. Frederick Jackson Turner notoriously argued that the West was the most significantly defining region for all of America, stating that "[t]he true point of view in the history of this nation is not the Atlantic coast, it is the Great West" (3). This approach, rendered deeply problematic by the New Western History for the last three decades, provided support for the great narrative of the West. Despite a new critical awareness, Turner's ideas continue to reverberate in the popular imagination (Cronon 160).

25 When Koike and other Japanese-American photographers took artful photographs in the locations around their homes along the West Coast in the 1920s and 1930s, they were joining many Americans in pursuit of regional explication. Koike and other Japanese-American pictorialists took part in regionalism, despite their seemingly 
different Japanese aesthetic and despite pictorialism's tendencies toward the general and the universal. The special link between pictorialism and regionalism was due to its accessibility as an aesthetic style for multitudes of amateurs who took up the medium with a minimum of training and part-time approach that excluded them from the elite of fine art photography. They were part of what one critic called "the broad movement" (Lamb 76).

26 Modernists sought to distinguish themselves from these developing hordes of dilettantes, and pictorialists embraced that rejection according to their growing regionalist values. The differences between regions and more well-known cultural centers were demonstrated through the crafted political rhetoric of self-proclaimed regionalists. American Scene painter Grant Wood, for instance, wrote in "Revolt against the City" (1935) that "the great central areas of America ... are not the hinterland for New York" (653). Likewise, southwestern author Mary Austin wrote "New York: Dictator of American Criticism" (1920), in which she stated that "New York is, in respect to the rest of our country, only a half-way house of immigration, a little less than a half-way house for European thinking." she also demanded that "if decentralization is the only way to accomplish the release of the American genius, that decentralization must inevitably take place" (129). The rise of regionalist articulation resounded in newspapers and journals across America, as well. For example, one columnist wrote that

A chief function of the arts is the interpretative function and it must be in a truly American art that the life of America is mirrored, realized, and critically examined. And to American arts regionalism must contribute, for New York can never symbolize America as Paris stands for France and London for England. The stretch of country is too great, sectional resources and employments are too various, the regional problems too diverse. (Dallas Morning News 8)

This type of regionalist sentiment certainly seemed pervasive and persuasive, clinging to notions of American exceptionalism. Moreover, the dichotomous tension expressed by these writers represents a simplified narrative of regionalism, one that did not privilege the immigrant, and failed to acknowledge the deep cultural inheritance from sources beyond their borders. Perhaps the discourse emphasized simplicity, but the cultural production did not.

28 Many in the 1920s and 1930s saw the delineation of the regionalist as provincial. For example, one columnist wrote in 1935 that "opposed to the regionalists are the 'internationalists,' who advocate the painting of any and all subjects, no matter what their locale," suggesting that regionalist subject matter was only of interest to the region ("Washington Artists Observe New 'Regionalism' Trend" 11). But in reality, most serious regionalists were producing cultural material for the consumption of the nation and the larger European sphere. Koike participated in the national debate over photographic style, writing essays and publishing photographs in journals such as Camera Craft, Photo-Era, The American Annual of Photography, and others,as well as exhibiting widely across the United States and in Europe (Martin and Bromberg 109-110). Indeed, the success of the pictorialists was not simply due to the support of art lovers from their own locales. Instead, these self-identified regionalists sought national and international recognition for their work. This larger conversation about aesthetics and region was not a contradiction to the tenets of the regionalist movement; rather, it demonstrates the mutability that inevitably had to exist given the 
decentralized nature of regionalism. The "rules" of regionalism were flexible according to medium, political affiliation, and a host of other defining conditions.

29 Regional evangelists oversimplified notions of commonality and difference. In its most essential definition, regionalism connected people to others based on local/ regional/sectional criteria and separated them from others outside the delimiting boundaries of that region-defining identity against a national ethos. The JapaneseAmerican regionalists, however, demonstrated the connectedness between cultural spheres of region and sub-region as well as region and nation. As immigrants, their adherence to a regional subject matter connected them to their local and regional community, but the very act of regional expression also enveloped them within the cultural sphere of the larger nation; to be a regionalist in the years around 1930 was a deeply American attitude no matter which region was represented. On the other hand, regionalism as expressed by Japanese immigrants demonstrated a broad cultural interactivity that highlighted obvious cultural differences. The aesthetics of pictorialism and "Japonisme" were an amalgamation of sources from around the world, the citizenry of pictorial camera clubs-through exhibition opportunities and published discourse-were globally engaged and the photographers themselves, culturally, politically, and ethnically were a diverse and transnationally dynamic group.

30 Despite their wide artistic purview, Koike, like others, believed in the importance of regional identity, which found expression as much in his writing as it did in his photographs. His "Photographing Mountains," which appeared in The American Annual of Photography in 1931, is practically an advertisement for the greatness of the Cascade and Olympic ranges in Washington State. He describes his interaction with the location as much as he does the creation of photographs. Even this approach to locale, however, is not without its complicating factors. Enamored with mountains and mountain photography, Koike responded with romantic and florid language to describe the places he visited. Moreover, Koike's personal understanding of the mountains of the Northwest was filtered through his original, cultural interaction with Japan's Mt. Fuji. Koike noted that "[t]he snow-cap" of Mt. Rainier "is similar in the form to our holy Mount Fuji, so we Japanese often call it "Tacoma Fuji"' (Fig. 3; "Mount Rainier" 117). While Koike's investment in the Pacific Northwest is clearly demonstrated, his understanding of region was profoundly multifaceted. 
Figure 3

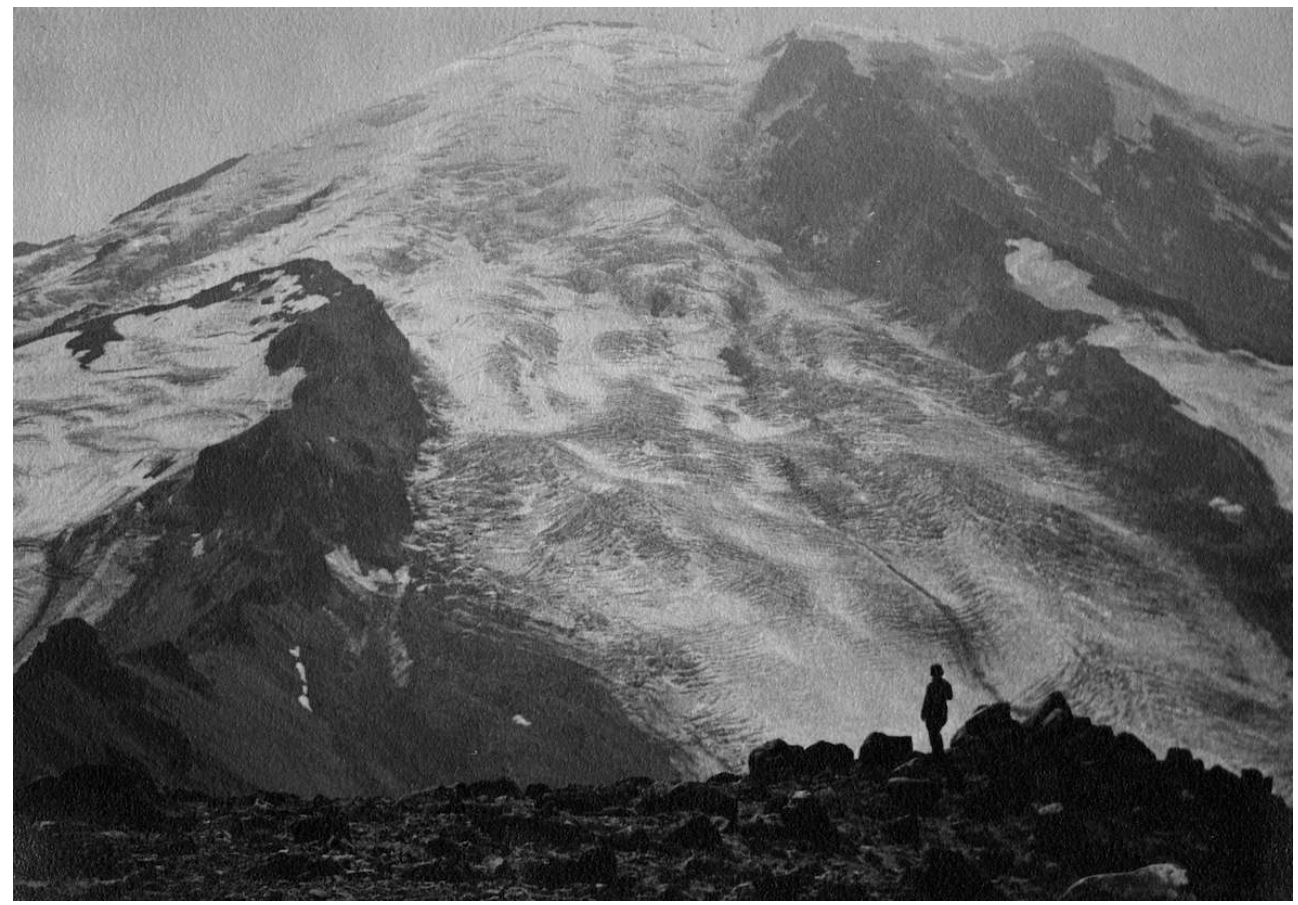

Kyo Koike, Glacier Inferno, ca. 1930 (University of Washington Special Collections, UW 36435)

${ }_{31}$ Besides region-oriented subject matter, however, the aesthetic of pictorialism itself began to be associated with regionalism. Often this association took on negative overtones-a retardataire style and a regionalist subject matter and intention were equated with provincialism by the elite in the art world. By the 1930s and 1940s, the modernist elite who were exhibiting in the Museum of Modern Art and the Guggenheim in New York City and the De Young Museum in San Francisco were people like Ansel Adams, Edward Weston, Paul Strand, and others who vociferously rejected the pictorial style. According to Adams, for instance, "the essential honesty and directness of the medium were nullified...when photography turned to a shallow restatement of the qualities and intentions of the painting and other graphic media of that period" (13). For him, the clarity of the photography associated with the "frontier" phase of the American West was a tradition to be revived, even as the legacy of that era had never really fallen away.

\section{Pictorialism and the History of Photography in the American West}

The relationship between the Nikkei, the pictorialist aesthetic, and American regionalism was further complicated by the entrenched photographic traditions associated with the American West. In this broad region of the United States, photography had always been used to investigate and define place. From the midnineteenth century, when Euro-Americans began their systematic incursions into the interior, to the end of the century, photographers were abundant across the subregions of the West. In one sense, western photographers took photographs for the nation, selling their wares in eastern, more populated locales. Other photographers settled in 
towns and cities and provided photographic services to their fellow settlers. These thousands of photographers, more so than the celebrities of nineteenth-century western photography, such as William Henry Jackson and Carleton Watkins, were responsible for a significant photographic legacy in the region (Sailor). Photography was not just a beneficial way to visibly capture a passing phase of Euro-American immigration; it was a tool for settlement. Photography allowed new residents and whole communities to imaginatively shape their conception of the new western places by applying normative aesthetic values onto an unknown landscape; by framing a place correctly, it was made to resemble something already known.

$3 з$ By the late 1920s, via this legacy, photography in the West was already intimately tied to the construction of self through place. In fact, the strong tradition of western photography supposed investigation of place by outsiders. Nineteenth-century western photographers were immigrants, using photography to investigate and construct meaning. When the Japanese Americans took up landscape photography in the twentieth century, they were thus joining a time-honored tradition. They were also confronting much of the myth that attended such an aggressive construction of regional identity. From the earliest years of the nineteenth century, the narrative of the West has largely been that of the Frontier myth, "which sees the discovery, conquest and settlement of the West as the dominant theme of American history," where "artists saw their mission as that of transforming the base materials of national 'history' and scenery into an evocative mythology, rich in symbolic resonance, which they could celebrate" (Slotkin 94). Far from an antiquated approach to the American West, the Frontier myth was ever present in Koike's era.

34 While Koike did not address the characteristics of "western-ness" in his writing, he did advocate for the natural world around Seattle, often describing in detail the best qualities of the local landscape. In "Mount Rainier," published in Camera Craft in 1926, Koike describes Mount Rainier National Park as "the pride of our charmed land" (117). He proceeds in this article to describe the pictorial opportunities at length, advising about hiking trails, weather, etc. Scene hunting was common among pictorialists all over the country, but it had a deeper meaning in the West, where photography associated with the Frontier highlighted danger, adventure, and the rhetoric of religious experience in confronting the region's hallowed places. Koike also associates his experience of the mountain with local legend by suggesting that Mt. Rainier was a "holy mountain which old Indians worshiped as a god," much in the way earlier Anglo immigrants would have understood the place ("Seattle Camera Club" 182).

35 In an essay in which Koike offered advice for those who would like to make a pictorialist photograph, he wrote that to understand his photographs "you must become dreamy and wander in the land of imagination" ("Japanese Art" 115). His eloquent summation of how to achieve a pictorialist photograph offers a striking similarity to the earlier manner in which photography was used in the West. While under the guise of "documenting" or "recording," scholars now understand much of the nineteenth-century cultural production of the West (indeed of America) as products of invention as well as imagination. Although "documentary" was not a meaningful term in the nineteenth century, it certainly describes the attitude toward photography: how immigrant settlers used the camera ostensibly emphasized accuracy and veracity in the medium. Many valued what they thought of as the truth-telling capabilities of the camera, despite its overwhelming use for promoting a particularly 
Eurocentric agenda for America. This seemingly straightforward photographic ethos from the mid-nineteenth century was rejected by late century emerging pictorialists who sought not to document but to create an overtly artful photographyovershadowing the centrality of imagination in both eras.

${ }_{36}$ Just as artists and photographers invented the mythic West through their own set of needs and desires, so too did the Japanese-American pictorialists contemplate place through their own cultural filters. Indeed, using one's imagination to photograph the West was directly in line with what newcomers to the West had done since the 1840s. In this way, Koike's transnational photographs were paradoxically truly American and truly western, responding as all-western image makers to a formidable and sometimes monolithic sense of place and identity.

\section{Conclusion}

The height of the regionalist movement in the United States was delineated by the two World Wars. World War I encouraged reflection on American identity within the contentious global politics that devastated Europe and destroyed economies. The years of the Great Depression, as well, encouraged Americans to value local communities and invest domestically in more ways than just fiscally. World War II proved an end marker for what we could think of as the golden age of American regionalism, when the international citizenry of the United States could not be denied. Most agree that things changed for Americans with the advent of World War II. For Japanese-Americans, change was undeniable.

38 Kyo Koike, along with most of his Japanese-American companions, was moved to the Minidoka War Relocation Center in Idaho, one of the many internment camps set up to house those of Japanese ancestry during World War II. Minidoka operated for just over three years from 1942 to 1945 . The general rule against cameras prevented Koike and others from pursuing pictorialism and he never resumed photography with the gusto he demonstrated previous to the war. He died two years after his release, in 1947.

39 An investigation into an aesthetic product of Koike, as representative of the Japanese-American photographers, and an analysis of the role of regionalism in his work is ultimately a mutually beneficial endeavor: the details of a specific instance of cultural production can illuminate the era's larger interest in region, and a more nuanced sense of region provides a framework in which to understand and evaluate cultural production. Japanese-American pictorialists along the West Coast participated in a cultural activity that both allowed them to conform to and make sense of their new home and to preserve ties to their native country. They were embroiled in a cultural negotiation that, whether intentional or not, reconciled disparate strands of form and function that emerged across some 70 years, from the European blossoming of pictorialism to the culmination of the style in mid-century America, and from sources around the world. 


\section{BIBLIOGRAPHY}

“A Mistaken Impression.” Camera Club 3.3 (1901): N.P. Print.

Adams, Ansel. Making a Photograph: An Introduction to Photography. London: The Studio Publications, 1935. Print.

Anderson, Paul. “Some Pictorial History.” American Photography 29.6 (1935): 199-215. Print.

Austin, Mary. "New York: Dictator of American Criticism." The Nation 111 (July 31, 1920): 129-30. Print.

Bent, A.F. "Camera Clubs and Club Activities." The Complete Photographer: An Encyclopedia of Photography. Ed. Willard D. Morgan. New York: National Educational Alliance, 1942. 544-53. Print. Blumann, Sigismund. “Our Japanese Brother Artists.” Camera Craft 32.3 (1925): 109. Print. Brown, E.H. "How to Organise and Maintain a Camera Club." Photo-Era 55.3 (September 2, 1925): 131-37. Print.

Bunnell, Peter C. Degrees of Guidance: Essays on Twentieth-Century American Photography. New York: Cambridge UP, 1993. Print.

Christiansen, C.W. “Pictorial Photography as I See It." Photo-Era 41.4 (October 1, 1918): 186-93. Print.

Corn, Wanda. The Great American Thing: Modern Art and National Identity, 1915-1935. Berkeley: U of California P, 1999. Print.

Cornell, Daniell. "Camera Work and the Fluid Discourse of Pictorialism." History of Photography 23.3 (Fall1999): 294-300.Print.

Cronon, William. "Revisiting the Vanishing Frontier: The Legacy of Frederick Jackson Turner." The Western Historical Quarterly 18.2 (1987): 157-76. Print.

Dallas Morning News (8 February, 1931): 8. Print.

Dow, Arthur Wesley. Composition. Berkeley: U of California P, 1997 [1920]. Print.

Harter, Wickham. “A Local Camera Club.” Popular Photography 4.6 (March 1, 1916): 276-79. Print.

Hartmann, Sadakichi. "A Few Reflections on Amateur and Artistic Photography." Camera Notes 2.3 (1898): 41-45. Print.

-. "The New York Camera Club." Photographic Times 32.2 (1900): 59-61. Print.

- [Allan, Sidney]. “A Plea for Good Taste and Common Sense.” The American Amateur Photographer 17.10 (October 1, 1905): 469-75. Print.

-. "Subject and Treatment." Camera Notes 5.3 (1902): 177-87. Print.

Holmes, Oliver Wendell. "The Stereoscope and the Stereograph." Atlantic Monthly 3.20 (1859): 738-48. Print.

Koike, Kyo. "Figures in Mountain Photography." The American Annual of Photography 48 (1934): 67-71. Print.

-. "The Influence of Old Japanese Literature and Arts on Pictorial Photography." American Photography 22.1 (1928): 16-19. Print. 
-. "Japanese Art in Photography." Camera Craft 32.3 (1925): 110-15. Print.

-. Kyo Koike Photograph Collection. Exhibition awards. VM 262. University of Washington Special Collections.

-. "Mountain Photography in Four Seasons." Photo Art Monthly 3.7 (1935): 318-26. Print.

-. "Mount Rainier." Camera Craft 33.3 (1926): 117-23. Print.

-. "My Photographic Trip.” The Miniature Camera 11.4 (1934): 129-31. Print.

-. "Photographing Mountains." The American Annual of Photography 45 (1931): 36-40. Print.

-. "Pictorial Photographic Salons." The American Annual of Photography 46 (1932): 36-40. Print.

-. "The Seattle Camera Club." Photo-Era Magazine 55.4 (1925): 182-88. Print.

Lamb, Louis A. "The Broad Movement in Pictorial Photography." The American Annual of Photography and Photographic Times Almanac (January 1, 1906): 74-77. Print.

McCauley, Elizabeth Anne. "The Making of a Modernist Myth.” The Steerage and Alfred Stieglitz, by Jason Francisco and Elizabeth Anne McCauley. Berkeley: U of California P, 2012. 16-65. Print.

Martin, David F., and Nicolette Bromberg. Shadows of a Fleeting World: Pictorial Photography and the Seattle Camera Club. Seattle: U of Washington P, 2011. Print.

Peterson, Christian. After the Photo-Secession: American Pictorial Photography, 1910-1955. New York: W.W. Norton and Company in association with the Minneapolis Institute of Arts, 1997. Print.

Powell, Douglas Reichert. Critical Regionalism: Connecting Politics and Culture in the American Landscape. Chapel Hill: The U of North Carolina P, 2007. Print.

Reed, Dennis. Japanese Photography in America 1920-1940. Los Angeles: Japanese American Cultural \& Community Center, 1985. Print.

Sailor, Rachel. Meaningful Places: Landscape Photographers in the Nineteenth-Century American West. Albuquerque: U of New Mexico P, 2014. Print.

Slotkin, Richard. "Visual Narrative and American Myth from Thomas Cole to John Ford." American Victorians and Virgin Nature. Ed. T.J. Jackson Lears. Boston: Isabella Stewart Gardner Museum, 2002. 91-112. Print.

Stieglitz, Alfred. “Pictorial Photography." Scribner's Magazine 26.5(1899): 528-537. Print.

Stellmann, L.J. “California Camera Club.” Photo-Era 19.4 (October 1, 1912): 171-74. Print.

Turner, Frederick Jackson. "The Significance of the Frontier in American History." Major Problems in the History of the American West. Ed. Clyde A. Milner. Lexington: D.C. Heath and Company, 1989 [1894]. 2-21. Print.

“Washington Artists Observe New ‘Regionalism’ Trend.” The Seattle Sunday Times (June 30, 1935): 11. Print.

Wood, Grant. "Revolt against the City." American is West: An Anthology of Middlewestern Life and Literature. Ed. John T. Flanagan. Minneapolis: U of Minnesota P, 1945. 648-60. Print.

\section{ABSTRACTS}

This essay contributes to the story of the Japanese immigrant pictorialists by examining the work and history of Kyo Koike, regional photographer and Seattle Camera Club member. I will 
demonstrate through this case study that historically, the notion of regionalism often embodied a transnational complexity that has gone unacknowledged. Within the details of Koike's photographic work, regionalism becomes a broad and encompassing cultural expression.

INDEX

Keywords: Camera club, Canada, Japan, Kyo Koike, photography, pictorialism, regionalism, transnationalism

\section{AUTHOR}

RACHEL SAILOR

University of Wyoming 